\title{
The Effect of Leadership Style and Compensation on Employee Performance at PT Sumber Sarana Berdikari in Tangerang
}

\author{
Rima Handayani \\ Universitas Pamulang \\ E-mail: dosen00551@unpam.ac.id
}

\begin{abstract}
Humans as one of the resources that are dynamic and have the ability to continue to grow need to get the attention of the company. This study aims to determine the effect of leadership style and compensation on employee performance at PT. Sumber Sarana Berdikari in Tangerang. The method used was explanatory research with a sample of 58 respondents. The analysis technique uses statistical analysis with regression testing, correlation, determination and hypothesis testing. The results of this study leadership style has a significant effect on employee performance by $47.4 \%$, hypothesis testing obtained significance 0,000 $<0.05$. Compensation has a significant effect on employee performance by $36.2 \%$, hypothesis testing obtained significance of $0,000<0.05$. Leadership style and compensation simultaneously have a significant effect on employee performance by $56.7 \%$, hypothesis testing obtained significance 0,000 $<0.05$.
\end{abstract}

Keywords : Leadership Style; compensation; employee performance.

\section{INTRODUCTION}

Globalization also brings changes in various aspects of the life of the world community, not least in the environment of various organizations or businesses that make it very volatile, full of change, and increasingly sharp competition. To win the competition and success of a company is not only dependent on real capital in the form of money, but one of the things that also plays a role is superior human resources in a company (Hasibuan, 2018; Niswaty, Juniati, Dervish, Salam, \& Arhas, 2019; Siagian, 2015). Because all raw materials and production machinery owned by the company will not be able to work without ideas and creativity from the employees, which are spread in various divisions with their respective duties and responsibilities (Edison, Anwar, \& Komariyah, 2016; Gomes, 2003; Samsuni, 2017)

Human resource management is a part of management science that studies human relations as assets and company resources and how to manage them (Darmawan, 2013; Darsono, 2011). Humans as one of the resources that are dynamic and have the ability to continue to grow need to get the attention of the company. Having superior human resources will produce good work. Behind superior human resources is the nature of leadership possessed by these human resources. Where the nature of leadership there are several styles called leadership styles. In addition to facing the problem of leadership styles of various characters, the company will also face demands from its employees regarding the policy of rights they will get after carrying out their obligations. A company is not only thinking about profits for the company, but the company must also think about the welfare of its employees. One of them is by giving 


\author{
40 Jurnal Administrare: Jurnal Pemikiran Ilmiah dan Pendidikan Administrasi Perkantoran \\ Vol. 7, No. 1, January - June 2020, Pages 39-48
}

compensation to employees (Dhermawan, Bagus, Sudibya, \& Utama, 2012; Kusuma \& Ardana, 2014; Supatmi, Nimran, \& Utami, 2018).

Employee performance is also influenced by leadership style and compensation (Mondiani, 2012; Nimpuno, 2015; Tampi, 2014). Where if someone has a leader who has a good leadership style and is given compensation that is proportional to his work, then the employee will provide the best performance results as well. According to (Effendi Marihot Tua, 2010) performance is the result of work produced by employees or actual behavior that is displayed in accordance with their role in the organization. Employee performance is a very important thing in an organization's efforts to achieve its goals.

The importance of leadership style possessed by a leader in achieving organizational goals, therefore the management needs to see what elements can build the birth style of leadership, one of which is to provide compensation. Leadership style is the nature of habits, temperament, character and personality that distinguishes a leader in interacting with others (Kartono, 2011). This understanding gives an understanding that every leader basically has a different behavior in leading his followers.

Compensation can be in the form of salaries, bonuses, incentives or other awards given in accordance with the work of the employees themselves planning. To deal with this, a company needs to think strategically with implementations tactically, so that it can optimally empower existing resources with the company's target.

Leadership style is an important aspect to achieve and improve the success of one's leadership in an organization (Akib \& Darwis, 2015; Lie, 2016; Niswaty et al., 2019). Leadership style is a pattern of approach or preferred method of directing and influencing others.

Proper compensation is expected to be able to arouse employee morale in completing work. With adequate compensation and a leader who cares about his subordinates carried out properly and successfully, then an employee will be compensated in carrying out the work assigned to him and try to overcome the problems that occur.

Performance is an embodiment of work done by employees which is usually used as a basis for evaluating employees or organizations, so it needs to be sought to improve work (Amirullah \& Saleh, 2015; Awaliah, Amirullah, \& Saleh, 2015). And the factors that influence compensation include: performance, quality of performance, work compensation.

\title{
METHOD
}

The type of research used is associative, where the aim is to find out the connection between. The population in this study amounted to 58 respondents PT. Sumber Sarana Berdikari in Tangerang. The sampling technique in this study is saturated sampling, where all members of the population are sampled. Thus the sample in this study amounted to 58 respondents. In analyzing the data used the instrument test, classical assumption test, regression, coefficient of determination and hypothesis testing. 


\section{RESULT AND DISCUSSION}

Leadership style is a way for leaders to influence their subordinates expressed in the form of behavior or personality patterns. A leader is someone who has a program and who behaves jointly with group members using certain methods or styles, so that leadership has the role of dynamic forces that encourage, compensate and coordinate the company in achieving the goals that have been created.

\section{Descriptive Analysis}

In this test used to determine the highest minimum and maximum scores, ratting scores and standard deviations of each variable. The results are as follows:

\section{Table 1}

Statistical Descriptive Analysis Results

Descriptive Statistics

\begin{tabular}{l|r|r|r|r|r}
\hline & N & Minimum & Maximum & $\begin{array}{c}\text { The } \\
\text { mean }\end{array}$ & Std. Deviation \\
\hline Leadership Style (X1) & 58 & 31 & 48 & 38.36 & 4,327 \\
\hline Compensation (X2) & 58 & 31 & 48 & 38.38 & 3,820 \\
\hline Employee Performance (Y) & 58 & 33 & 46 & 39.29 & 3,613 \\
\hline Valid N (listwise) & 58 & & & & \\
\hline
\end{tabular}

Leadership style obtained a minimum variance of 31 and a maximum variance of 48 with a ratting score of 38.36 with a standard deviation of 4.327 . Compensation obtained a minimum variance of 31 and a maximum variance of 48 with a ratting score of 38.38 with a standard deviation of 3,820. Employee performance obtained a minimum variance of 33 and a maximum variance of 46 with a ratting score of 39.29 with a standard deviation of 3,613.

\section{Multiple Regression Analysis}

This regression test is intended to determine changes in the dependent variable if the independent variable changes. The test results are as follows:

\section{Table 2}

\section{Multiple Regression Testing Results}

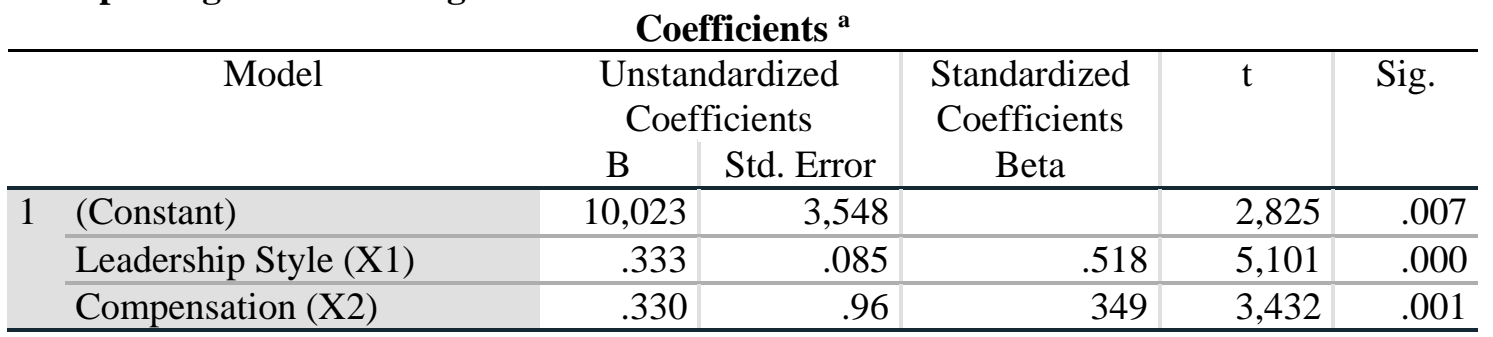

a. Dependent Variable: Employee Performance (Y) 


\section{Jurnal Administrare: Jurnal Pemikiran Ilmiah dan Pendidikan Administrasi Perkantoran Vol. 7, No. 1, January - June 2020, Pages 39-48}

Based on the test results in the above table, the regression equation $\mathrm{Y}=10.023+$ $0.433 \mathrm{X} 1+0.330 \mathrm{X} 2$ is obtained. A constant of 10,023 means that if there is no leadership and compensation style, then there is an employee performance value of 10,023 points. The leadership style regression coefficient is 0.433 , this number is positive, meaning that every time there is an increase in leadership style by 0.433 , the employee's performance will also increase by 0.433 points. The compensation regression coefficient is 0.330 , this number is positive, meaning that every time there is an increase in compensation by 0.330 , the employee's performance will also increase by 0.330 points.

\section{Correlation Coefficient Analysis}

Correlation coefficient analysis is intended to determine the degree of relationship strength of the independent variables on the dependent variable either partially or simultaneously. The test results are as follows:

\section{Table 3}

\section{Correlation Coefficient Test Results Leadership Style On Employee Performance} Correlations $^{\text {b }}$

\begin{tabular}{llr|r}
\hline & & \multicolumn{2}{|c}{$\begin{array}{c}\text { Employee } \\
\text { Performance } \\
\text { (Y) }\end{array}$} \\
\hline Leadership Style (X1) & Pearson Correlation & 1 & $.689^{* *}$ \\
& Sig. (2-tailed) & $.689^{* *}$ & .000 \\
\hline Employee Performance (Y) & Pearson Correlation & .000 & 1 \\
\cline { 2 - 4 } & Sig. (2-tailed) & & \\
\hline
\end{tabular}

**. Correlation is significant at the 0.01 level (2-tailed).

b. Listwise $\mathrm{N}=58$

Based on the test results obtained by the correlation value of 0.689 means that the leadership style has a strong relationship with employee performance.

Table 4

Compensation Correlation Coefficient Test Results on Employee Performance.

Correlations $^{\text {b }}$

\begin{tabular}{llr|r}
\hline & & $\begin{array}{c}\text { Compensation } \\
(\mathrm{X} 2)\end{array}$ & $\begin{array}{r}\text { Employee Performance } \\
(\mathrm{Y})\end{array}$ \\
\hline Compensation (X2) & Pearson Correlation & 1 & $.602^{* *}$ \\
\cline { 2 - 5 } & Sig. (2-tailed) & & .000 \\
\hline $\begin{array}{l}\text { Employee Performance } \\
\text { (Y) }\end{array}$ & Pearson Correlation & $.602^{* *}$ & 1 \\
\cline { 2 - 5 } & Sig. (2-tailed) & .000 & \\
\hline
\end{tabular}

**. Correlation is significant at the 0.01 level (2-tailed).

b. Listwise $\mathrm{N}=58$ 
Based on the test results obtained a correlation value of 0.602 means that compensation has a strong relationship with employee performance.

Table 5

Test Results Correlation Coefficient of Leadership Style and Simultaneous Compensation on Employee Performance.

\begin{tabular}{|c|c|c|c|c|}
\hline \multicolumn{5}{|c|}{ Model Summary } \\
\hline Model & $\mathrm{R}$ & R Square & $\begin{array}{l}\text { Adjusted R } \\
\text { Square }\end{array}$ & $\begin{array}{l}\text { Std. Error of the } \\
\text { Estimate }\end{array}$ \\
\hline 1 & $.753^{\mathrm{a}}$ & .567 & .551 & 2.420 \\
\hline
\end{tabular}

a. Predictors: (Constant), Compensation (X2), Leadership Style (X1)

Based on the test results obtained a correlation value of 0.753 means that the leadership style and compensation simultaneously have a strong relationship to employee performance.

\section{Analysis of the Coefficient of Determination}

Analysis of the coefficient of determination is intended to determine the percentage of influence of the independent variable on the dependent variable either partially or simultaneously. The test results are as follows:

Table 6

Test Results for the Leadership Style Coefficient Determination of Employee Performance Model Summary

\begin{tabular}{lrrrr|r}
\hline Model & $\mathrm{R}$ & R Square & \multicolumn{1}{c}{$\begin{array}{c}\text { Adjusted R } \\
\text { Square }\end{array}$} & $\begin{array}{c}\text { Std. Error of the } \\
\text { Estimate }\end{array}$ \\
\hline 1 & & $.689^{\mathrm{a}}$ & .474 & .465 & 2.642 \\
\hline
\end{tabular}

a. Predictors: (Constant), Leadership Style (X1)

Based on the test results obtained a determination value of 0.474 means that the leadership style has an influence contribution of $47.4 \%$ on employee performance.

Table 7

Efficient Co-Test Results Determination of Compensation for Employee Performance.

Model Summary

\begin{tabular}{|c|c|c|c|c|}
\hline Model & $\mathrm{R}$ & R Square & $\begin{array}{l}\text { Adjusted R } \\
\text { Square }\end{array}$ & $\begin{array}{l}\text { Std. Error of the } \\
\text { Estimate }\end{array}$ \\
\hline$\overline{1}$ & $.602^{\mathrm{a}}$ & .362 & .351 & 2.910 \\
\hline
\end{tabular}

a. Predictors: (Constant), Compensation (X2)

Based on the test results obtained a determination value of 0.362 means that compensation has an influence contribution of $36.2 \%$ on employee performance. 


\section{$44 \mid$ Jurnal Administrare: Jurnal Pemikiran Ilmiah dan Pendidikan Administrasi Perkantoran Vol. 7, No. 1, January - June 2020, Pages 39-48}

\section{Table 8}

Test Results for the Leadership Style Coefficient Determination and Compensation for Employee Performance.

Model Summary

\begin{tabular}{lrr|rr|r}
\hline Model & & \multicolumn{2}{c|}{$\begin{array}{c}\text { Adjusted R } \\
\text { Square }\end{array}$} & \multicolumn{2}{c}{$\begin{array}{c}\text { Std. Error of the } \\
\text { Estimate }\end{array}$} \\
\hline 1 & $\mathrm{R}$ & \multicolumn{2}{|c|}{ R Square } & .551 & 2.420 \\
\hline
\end{tabular}

a. Predictors: (Constant), Compensation (X2), Leadership Style (X1)

Based on the test results obtained a determination value of 0.567 means that the leadership style and compensation simultaneously have an influence contribution of $56.7 \%$ on employee performance, while the remaining $43.3 \%$ is influenced by other factors.

\section{Hypothesis testing}

Hypothesis testing with $\mathrm{t}$ test is used to find out which partial hypotheses are accepted.

Table 9

Results of the Leadership Style Hypothesis on Employee Performance. Coefficients $^{\text {a }}$

\begin{tabular}{|c|c|c|c|c|c|c|}
\hline & \multirow[t]{2}{*}{ Model } & \multicolumn{2}{|c|}{$\begin{array}{l}\text { Unstandardized } \\
\text { Coefficients }\end{array}$} & \multirow{2}{*}{$\begin{array}{c}\text { Standardized } \\
\text { Coefficients } \\
\text { Beta } \\
\end{array}$} & \multirow[t]{2}{*}{$\mathrm{t}$} & \multirow[t]{2}{*}{ Sig. } \\
\hline & & B & Std. Error & & & \\
\hline & (Constant) & 17232 & 3,122 & & 5,519 & .000 \\
\hline & Leadership Style (X1) & .575 & .081 & 689 & 7,110 & .000 \\
\hline
\end{tabular}

a. Dependent Variable: Employee Performance (Y)

Based on the test results in table 9, the value of $t_{\text {count }}>t_{\text {table }}$ or (7.110>2.003), thus the first hypothesis proposed that there is a significant influence between leadership style on employee performance is accepted.

Table 10

Compensation Hypothesis Test Results on Employee Performance.

Coefficients $^{\text {a }}$

\begin{tabular}{|c|c|c|c|c|c|c|}
\hline \multirow{2}{*}{\multicolumn{2}{|c|}{ Model }} & \multicolumn{2}{|c|}{$\begin{array}{c}\text { Unstandardized } \\
\text { Coefficients }\end{array}$} & \multirow{2}{*}{$\begin{array}{c}\text { Standardized } \\
\text { Coefficients } \\
\text { Beta } \\
\end{array}$} & \multirow[b]{2}{*}{$\mathrm{t}$} & \multirow[b]{2}{*}{ Sig. } \\
\hline & & B & Std. Error & & & \\
\hline \multirow[t]{2}{*}{1} & (Constant) & 17,440 & 3,892 & & 4,481 & .000 \\
\hline & Compensation (X2) & .569 & .101 & 602 & 5,642 & .000 \\
\hline
\end{tabular}

a. Dependent Variable: Employee Performance (Y)

Based on the test results on the table above, the value of $t$ count $>t$ table or $(5.642>2.003)$ is obtained, thus the second hypothesis proposed that there is a significant effect on compensation 
for employee performance is received. Hypothesis testing with the F test is used to find out which simultaneous hypotheses are accepted.

Table 11.

Hypothesis Test Results Leadership and Compensation for Employee Performance.

\begin{tabular}{|c|c|c|c|c|c|c|}
\hline & & ANOVA & & & & \\
\hline & & Sum of Squares & $\mathrm{df}$ & Mean Square & $\mathrm{F}$ & Sig. \\
\hline 1 & Regression & 421,973 & 2 & 210,986 & 36,033 & $.000^{b}$ \\
\hline & Residual & 322,044 & 55 & 5,855 & & \\
\hline & Total & 744,017 & 57 & & & \\
\hline
\end{tabular}

a. Dependent Variable: Employee Performance (Y)

b. Predictors: (Constant), Compensation (X2), Leadership Style (X1)

Based on the test results on the table above, the calculated $F$ value $>F_{\text {table }}$ or $(36.033>2.700)$, thus the third hypothesis proposed that there is a significant influence between leadership style and compensation on employee performance is accepted.

\section{CONCLUSION}

Based on your result showed that $g$ aya leadership significantly influence employee performance with a contribution of $47.4 \%$ influence. Hypothesis testing obtained values of $t$ count $>\mathrm{t}$ table or (7.110>2.003). Compensation has a significant effect on employee performance with an influence contribution of 36.2\%. Hypothesis testing obtained $t$ count $>t$ table or (5.642>2.003). Leadership style and compensation significantly influence employee performance with an influence contribution of $56.7 \%$ while the remaining $43.3 \%$ is influenced by other factors. Hypothesis testing obtained the value of $F_{\text {count }}>F_{\text {table }}$ or $(36.033>2.700)$.

\section{REFERENCES}

Akib, H., \& Darwis, M. (2015). Pengaruh Gaya Kepemimpinan Transformasional Kepala Sekolah Terhadap Kinerja Guru Pada SMK Negeri 1 Bungoro Kabupaten Pangkep. Jurnal Office, 1(1), 80-87.

Amirullah, A. H., \& Saleh, S. (2015). Pengaruh Budaya Organisasi terhadap Kinerja Pegawai Pada Kantor Lembaga Penjaminan Mutu Pendidikan (LPMP) Provinsi Sulawesi Selatan di Kota Makassar. Jurnal Office, 1(1), 24-31.

Awaliah, N., Amirullah, A. H., \& Saleh, S. (2015). Kinerja Pegawai Negeri Sipil pada Kantor Kementerian Agama Kota Makassar. Jurnal Office, 1(1), 13-17.

Darmawan, D. (2013). Prinsip-Prinsip Perilaku Organisasi. In Surabaya Pena Semesta.

Darsono. (2011). Manajemen Sumber Daya Manusia Abad 21. In Manajemen Sumber Daya 
46 | Jurnal Administrare: Jurnal Pemikiran Ilmiah dan Pendidikan Administrasi Perkantoran Vol. 7, No. 1, January - June 2020, Pages 39-48

\section{Manusia Abad 21.}

Dhermawan, Bagus, A. A. N., Sudibya, I. G. A., \& Utama, I. W. M. (2012). Pengaruh Motivasi, Lingkungan Kerja, Kompetensi dan Kompensasi Terhadap Kepuasan Kerja dan Kinerja Pegawai. Jurnal Manajemen, Strategi Bisnis, Dan Kewirausahaan.

Edison, E., Anwar, Y., \& Komariyah, I. (2016). Manajemen Sumber Daya Manusia. In Manajemen Sumber Daya Manusia.

Effendi Marihot Tua. (2010). Manajemen Sumber Daya Manusia : Pengadaan, Pengembangan, Pengkomprehensipan dan Peningkatan Produktivitas Pegawai. In Koleksi Buku UPT Perpustakaan Universitas Negeri Malang.

Gomes, F. C. (2003). Manajemen sumber daya manusia. Yogyakarta: Andi.

Hasibuan. (2018). Manajemen Sumber Daya Manusia. In Manajemen Sumber Daya Manusia.

Kartono, K. (2011). Pemimpin dan Kepemimpinan. Jakarta: Rajawali Grafindo Perkasa.

Kusuma, I., \& Ardana, K. (2014). Pengaruh Penempatan dan Kompensasi Terhadap Kepuasan Kerja dan Kinerja Karyawan. E-Jurnal Manajemen Universitas Udayana.

Lie, E. S. (2016). Pengaruh Komitmen Organisasional Dan Perilaku Kepemimpinan Terhadap Kualitas Pelayanan Bank NTT. Jurnal Ilmiah Ilmu Administrasi Publik, 5(2), 64-72.

Mondiani, T. (2012). Pengaruh Kepemimpinan Transformasional Dan Kompensasi Terhadap Kinerja Karyawan Pt. Pln (Persero) Upj Semarang. In Jurnal Administrasi Bisnis. https://doi.org/10.14710/jab.v1i1.4317

Nimpuno, G. A. (2015). Pengaruh Displin Kerja Dan Gaya Kepemimpinan Terhadap Kinerja Karyawan UD. Pustaka Pelajar Yogyakarta.

Niswaty, R., Juniati, F., Darwis, M., Salam, R., \& Arhas, S. H. (2019). The Effectiveness of Leadership Functions Implementation in The Makassar Departement of Manpower. JPBM (Jurnal Pendidikan Bisnis Dan Manajemen), 5(1), 1-10.

Samsuni, S. (2017). Manajemen sumber daya manusia. Al-Falah: Jurnal Ilmiah Keislaman Dan Kemasyarakatan.

Sanjaya, W. (2008). Kurikulum Dan Pembelajaran (Teori \& Praktek KTSP).

Sanjaya, W. (2010). Strategi Pembelajaran Berorientasi Standar Proses Pendidikan. System.

Sanjaya, W. (2015). Perencanaan dan Desain Sistem Pembelajaran. Kencana,Prenadamedia Group.

Siagian, S. P. (2015). Manajemen Sumber Daya Manusia. In Jakarta : Bumi Aksara.

Supatmi, M. E., Nimran, U., \& Utami, H. N. (2018). Pengaruh Pelatihan, Kompensasi terhadap Kepuasan Kerja Karyawan dan Kinerja Karyawan. Jurnal Profit Volume 7.

Tampi, B. J. (2014). Pengaruh Gaya Kepemimpinan dan Motivasi Terhadap Kinerja Karyawan Pada PT. Bank Negara Iindonesia, TBK (Regional Sales Manado). Jurnal 'Acta Diurna' Volume III. No.4. 
Rima Handayani; The Effect of Leadership Style and Compensation on Employee ... $\mid 47$

Uno, H. H. B. (2010). Model pembelajaran: menciptakan proses belajar mengajar yang kreatif dan efektif. In Jakarta: Bumi Aksara. https://doi.org/10.1038/cddis.2011.1 
48 Jurnal Administrare: Jurnal Pemikiran Ilmiah dan Pendidikan Administrasi Perkantoran Vol. 7, No. 1, January - June 2020, Pages 39-48 